\title{
PENGARUH PENDAPATAN ASLI DAERAH DAN ALOKASI UMUM TERHADAP BELANJA LANGSUNG DAN DAMPAKNYA TERHADAP PERTUMBUHAN EKONOMI DI KOTA BITUNG
}

\author{
Feronika, Vekie A. Rumate, Een N. Walewangko \\ Fakultas Ekonomi dan Bisnis, Magister Ilmu Ekonomi \\ Universitas Sam ratulangi
}

\begin{abstract}
ABSTRAK
Pendapatan Asli Daerah (PAD) merupakan salah satu komponen utama pemerintah daerah dalam menunjang alokasi anggaran pembangunan yang juga ditunjang oleh pemerintah pusat melalui pengalokasian Dana Alokasi Umum guna meningkatkan Belanja Langsung dan tujuan akhirnya adalah peningkatan pertumbuhan ekonomi daerah. Dengan adanya pertumbuhan ekonomi daerah diharapkan akan memberi efek domino dan berdampak pada peningkatan kesejahteraan masyarakat.

Dalam penelitian ini digunakan analisis path atau analisis jalur untuk mengetahui seberapa besar pengaruh dua variable independen terhadap satu variable ndependent dan pengaruh secara tidak langsung terhadap variable dependen kedua. Dimana didapatkan hasil positif antara pendapatan asli daerah dan dana alokasi umum terhadap belanja langsung dan dampaknya terhadap pertumbuhan ekonomi di Kota Bitung.

Kata kunci : Pendapatan Asli Daerah (PAD), Dana Alokasi Umum (DAU), Belanja Langsung, Pertumbuhan Ekonomil
\end{abstract}

\begin{abstract}
Local Revenue is one of the main components of local government in supporting the development budget allocation is also supported by the central government through the allocation of general allocation funds in order to increase direct expenditure and the final goal is the improvement of the regional economy. With the region's economic growth is expected to be also a positive domino effect and impact on improving people's welfare.

This study used path analysis or path analysis to determine how much influence the two variables are independent of one variable independent and indirect influence on both the dependent variable. Where the positive results obtained between the local revenue and general allocation of funds towards direct spending and its impact on economic growth in the city of Bitung.
\end{abstract}

Keywords : $\quad$ Local revenue, General Allocation Fund, Direct Expenditure, Economic Growth 


\section{Latar Belakang}

\section{PENDAHULUAN}

Pemberdayaan perekonomian daerah merupakan tujuan bersama baik dari daerah maupun dari pemerintah pusat. Dengan adanya perekonomian daerah yang kuat tentunya akan berdampak pada perekonomian nasional secara keseluruhan. Dengan adanya tujuan peningkatan perekonomian hingga ke pelosok dan guna mensejahterakan masyarakat daerah berbagai program desentralisasi terus digalakan, hal inilah yang tertuang dalam semangat otonomi. Pembangunan daerah dengan memaksimalkan potensi yang dimiliki tentu harus bisa dijalankan oleh pemerintah daerah, namun sebelum itu perlu adanya identifikasi sector-sektor serta potensi-potensi apa saja yang dimiliki oleh daerah, agar bisa memaksimalkan sumber daya yang ada. Pembangunan yang berorientasi pada kesejahteraan masyarakat serta perimbangan pembangunan antara pusat dan daerah merupakan tujuan utama dari adanya program desentralisasi, karena pemerintah yang ada di daerah dianggap lebih mengetahui apa saja kebutuhan daerah, serta perlakuan apa yang harus diberikan agar potensipotensi yang dimiliki oleh daerah dapat dimanfaatkan secara lebih maksimal.

Upaya peningkatan perekonomian suatu daerah tentu tak bisa lepas dari peran serta pemerintah, instansi terkait serta investor maupun masyarakat untuk bersama-sama menstimulus perekonomian dan pada akhirnya meningkatkan pertumbuhan ekonomi yang ada. Sebuah pembangunanan ekonomi adalah proses dimana pemerintah masyarakat serta pihak terkait mengelola dan memanfaatkan sumber daya yang secara maksimal serta membentuk lapangan kerja baru guna memaksimalkan potensi pertumbuhan ekonomi di dalam wilayah tersebut. Dewasa ini di berbagai daerah masih belum bisa menggelola dengan maksimal sektor-sektor perekonomian yang dimiliki dan masih tingginya tingkat ketergantungan terhadap dana dari pemerintah pusat.Pendapatan Asli Daerah (PAD) yang masih tergolong rendah membuat pemerintah daerah belum bisa meningkatkan kemandiriannya yang berimbas pada pembangunan yang dilakukan di daerah yang bersangkutan sehingga masih tingginya tingkat kemiskinan yang dimiliki di daerah, karena kurangnya kesempatan kerja dan sedikit investor yang ingin menanamkan modalnya di sebuah daerah yang belum bisa menyediakan sarana dan prasarana investasi yang memadai. Akibatnya pemerintah pusat harus rela menanggung beban pengeluaran sebuah daerah dengan kucuran Dana Transfer untuk menggenjot Anggaran Pendapatan dan Belanja Daerah (APBD). Undang-Undang No 33 Tahun 2004 tentang perimbangan keuangan antara pemerintah pusat dan daerah telah digulirkan pada 1 Januari 2001. Adanya Undang-Undang tersebut telah mengakibatkan pergeseran paradigma penyelenggaraan pemerintah dari paradigma sentralistis ke arah desentralisasi yang ditandai dengan pemberian otonomi yang luas dan nyata kepada daerah. Hal ini tentu menjadi jalan bagi pemerintah daerah untuk lebih maksimal dalam memanfaatkan dan mengelola sumbersumber ekonomi yang dimilikinya, meskipun tidak sedikit masalah yang dihadapi dalam pelaksanaannya oleh karena itu, pemerintah mengeluarkan Undang-Undang No.32 Tahun 2004 tentang pemerintahan daerah dan Undang-Undang No.33 Tahun 2004 tentang perimbangan keuangan antara pemerintah pusat dan pemerintah daerah.

Saat ini guna menunjang pembangunan di daerah tentu dibutuhkan sumber-sumber pendapatan yang tidak sedikit antara lain dari Pendapatan Asli Daerah (PAD), serta Dana Transfer dari Pemerintah Pusat. Dalam era otonomi daerah seperti saat ini tentu proses pendelegasian wewenang yang diberikan pemerintah pusat dibarengi dengan tugas dan tanggung jawab yang besar untuk bisa lebih memaksimalkan potensi-potensi yang dimiliki oleh daerah untuk dapat berkembang ke arah yang lebih baik. Pengalihan pembiayaan dari pusat ke daerah atau yang lebih dikenal sebagai desentralisasi fiscal, dapat pula diartikan sebagai suatu proses distribusi anggaran dari pemerintah yang lebih tinggi kepada pemerintah yang lebih rendah untuk kemudian dikelola guna mendukung fungsi atau tugas pemerintahan dan pelayanan public sesuai dengan banyaknya wewenang bidang pemerintahan yang diberikan atau dilimpahkan oleh pemerintah pusat (Saragih 2003 : 82). Dalam hubungannya, antara pemerintah pusat dan daerah menyangkut desentralisasi 
fiscal, dana perimbangan merupakan salah satu komponen utama yang mempengaruhi tingkat kemampuan daerah tersebut dalam mecukupi kebutuhan anggaran belanjanya di setiap periode. Perimbangan keuangan merupakan salah satu bentuk hubungan antara pemerintah pusat dan daerah dari sekian banyak hubungan yang dimilikinya, hubungan ini sendiri bersifat (intergovernmental fiscal relation system), sebagai salah satu bentuk kerjasama dalam pendelegasian wewenang pemerintah.

Dalam kenyataannya sendiri prosentase kemampuan daerah dalam membiayai pengeluarannya masih kecil dan sebagian besar masih berharap pada dana transfer dari pemerintah pusat. Sebagian besar wilayah Indonesia masih sangat kecil yakni masih berada di kisaran 25\% dari Total Penerimaan Daerah (TPD), hal ini menunjukan bahwa pendapatan daerah guna menyokong anggaran belanjanya masih dditopang sebagian besarnya oleh dana transfer pemerintah pusat dan sumbangan-sumbangan lainnya yang sah dan telah diatur di dalam undang-undang yakni sebesar 75\% persen dari Total Pendapatan Daerah (TPD). Hal ini tentu mengindikasikan bahwa kemampuan daerah untuk dapat mengatur perekonomian serta potensi yang dimilikinya masih sangat terbatas karena factor ketergantungan kepada pemerintah pusat yang masih amat besar, sehingga banyak kebijakan dari pemerintah pusat dalam pengelolaan potensi sumber keuangan harus diikuti oleh pemerintah daerah, dan sumber-sumber keuangan yang potensial masih tetap dikuasai oleh pemerintah pusat (Yani,2002:3). Sulawesi Utara adalah daerah yang berada di ujung utara pulau sulawesi dan berada di kawasan timur Indonesia merupakan salah satu daerah yang tengah menjadi sorotan baik di Indonesia bahkan dunia. Perputaran ekonomi yang cepat serta banyaknya peluang investasi yang kian terbuka menyebabkan perekonomian ikut terpacu. Letak geografis di bibir pasifik menjadikannya daerah yang berpotensi menjadi pusat perdagangan bukan hanya kawasan Indonesia Timur namun juga pusat perdagangan dunia. Saat ini berbagai sumber perekonomian potensial terus digalakan pemerintah, mulai dari berbagai iven international, pembangunan jalan tol kedua di pulau sulawesi yang menghubungkan Manado-Bitung serta kawasan ekonomi khusus (KEK) dan International Hub Port (IHP) Bitung. Hal ini tentu merangsang investor dan pemodal baik dari sektor swasta dan pemerintah, dalam maupun luar negeri untuk menanamkam modalnya di bumi nyiur melambai. Hal ini tentu bertujuan bukan hanya demi keuntungan sesaat namun guna menunjang peningkatan perekonomian serta membuka akses global melalui komunitas masyarakat asean dengan Kota Manado sebagai ibukotanya. Pasca adanya otonomi daerah kota Bitung sebagai kota Industri di Sulawesi Utara semakin menunjukan perkembangannya dari tahun ke tahun. Juga kota Bitung sebagai gerbang perdagangan baik nasional maupun internasional. Dengan adanya peningkatan yang semakin baik maka diharapkan akan menggenjot perekonomian ke arah yang semakin baik. Pemerintah Kota Bitung sebagai pemerintah daerah yang mempunyai kewenangan yang semakin besar dengan adanya desentralisasi diharapkan dapat melihat dan mengidentifikasi sector-sektor perekonomian unggulan dan dapat menggenjot sector-sektor ekonomi tersebut sehingga dapat berimbas pada kemampuan daerah yang semakin baik. Selain melihat sector-sektor perekonomian yang sudah ada, pemerintah daerah juga diharapkan untuk meningkatkan pendapatan asli daerah yang dimiliki sehingga sedikit demi sedikit akan semakin mengurangi ketergantungan terhadap pemerintah pusat. salah satu cara yang bisa dilakukan adalah dengan membuka sector-sektor ekonomi baru dengan melihat potensi yang dimiliki oleh daerah. Dengan adanya sumber-sumber pendapatan asli daerah dari sumber yang baru maka diharapkan kemandirian akan semakin tinggi dan pada akhirnya pemerintah daerah tidak lagi bergantung pada alokasi anggaran dari pemerintah pusat untuk membiayai anggaran rumah tangganya. Didasari oleh kesadaran inilah, perhatian besar dan sungguh-sungguh dari Pemerintah Daerah Provinsi dan Pemerintah Daerah Kabupaten/kota untuk dapat meningkatkan faktor kemampuan daerah dalam membiayai APBDnya sendiri perlu untuk ditingkatkan guna mengurangi proporsi dana transfer pemerintah pusat dalam Total Penerimaan Daerah (TPD), yang merupakan salah satu tolak ukur tingkat kemandirian suatu daerah. Salah satu cara paling nyata adalah melihat 
bagaimana penerimaan daerah dalam bentuk Pendapatan Asli Daerah dan Dana Alokasi Umum berpengaruh terhadap alokasi belanja pembangunan yang dilakukan pemerintah dalam bentuk belanja langsung yang didalamnya terkandung alokasi belanja modal, belanja barang jasa dan belanja pegawai dan bagaimana hal tersebut memberi dampak pada pertumbuhan ekononomi yang terjadi di Kota Bitung.

\section{Rumusan Masalah}

Tujuan utama dari pelaksanaan Otonomi adalah untuk membagi tanggung antara pemerintah pusat dan daerah yang bersangkutan, agar jalannya pemerintahan serta pelayanan masyarakat yang lebih terfokus karena pemerintah di daerah tentu lebih mengetahui permasalahan serta kebutuhan di daerah yang bersangkutan. Selain itu kemampuan sebuah daerah untuk mengelola serta memanfaatkan anggaran rumah tangganya sendiri sehingga bisa mencapai tahap yang maksimal dan dengan tujuan mensejahterakan masyarakat di daerah. Hal ini tentu menarik untuk diteliti untuk melihat seberapa besar kontribusi pendapatan asli daerah (PAD) dan Dana Alokasi Umum (DAU) terhadap alokasi belanja pembangunan pemerintah daerah yang tertuang dalam belanja langsung, serta melihat bagaimana dampaknya terhadap pertumbuhan ekonomi yang terjadi di kota Bitung. Berdasarkan latar belakang yang ada maka rumusan masalah yang akan diangkat dalam penelitian adalah Bagaimana Pengaruh Pendapatan Asli Daerah dan Dana Alokasi Umum terhadap Belanja Langsung dan dampaknya terhadap pertumbuhan ekonomi ?.

\section{Tujuan Penelitian}

Tujuan penelitian ini adalah untuk melihat seberapa besar pengaruh yang diberikan oleh Pendapatan Asli Daerah (PAD) dan Dana Alokasi Umum (DAU) terhadap alokasi Belanja Langsung dan dampaknya terhadap pertumbuhan ekonomi. Secara spesifik penelitian ini bertujuan

1. Untuk mengetahui Pengaruh Pendapatan Asli Daerah (PAD) terhadap alokasi Belanja Langsung di Kota Bitung.

2. Untuk mengetahui Pengaruh Dana Alokasi Umum (DAU) terhadap alokasi Belanja Langsung di Kota Bitung.

3. Untuk mengetahui Pengaruh Pendapatan Asli Daerah (PAD) dan Dana Alokasi Umum (DAU) secara bersama-sama terhadap alokasi Belanja Langsung dan dampaknya pada pertumbuhan ekonomi di Kota Bitung. Baik secara langsung maupun tidak langsung.

\section{Manfaat Penelitian}

1. Sebagai bahan masukan bagi pemerintah Kota Bitung untuk mengetahui perkembangan perekonomiannya, terlebih dari sektor Pendapatan Asli Daerah, Dana Alokasi Umum dan Belanja Langsung.

2. Untuk melihat bagaimana perkembangan Anggaran Pendapatan dan Belanja Daerah terhadap tingkat kemiskinan.

3. Untuk digunakan pihak yang berkepentingan untuk menganalisa masalah-masalah yang berhubungan dengan Pengelolaan fiskal Kota Bitung.

\section{Data dan Sumber Data}

\section{METODE PENELITIAN}

Data yang digunakan dalam penelitian ini adalah data anggaran dan pendapatan daerah kota Bitung dari tahun 2006-2015 dan bersumber dari Badan Pusat Statistik dan Bappeda kota Bitung.

\section{Definisi Operasional Variabel}


PAD : adalah pendapatan asli daerah kota Bitung yang bersumber dari pajak dan retribusi, maupun PAD lain yang sah

DAU : adalah dana Alokasi Umum yang bersumber dari dana transfer atau dana perimbangan dari pemerintah pusat ke daerah, yang pengalokasiannya disesuaikan dengan kebutuhan daerah.

Belanja langsung : adalaha alokasi belanja pemerintah daerah yang digunakan untuk membiayai pembangunan yang didalamnnya terkandung belanja modal, belanja barang jasa, dan belanja pegawai.

Pertumbuhan Ekonomi : adalah tingkat pertumbuhan atau peningkatan perekonomian yang terjadi di kota Bitung dengan mengacu pada PDRB.

\section{Metode Analisis}

Metode analisis yang akan digunakan dalam penelitian ini adalah Analisis Path. Yaitu untuk mengetehui Pengaruh Variabel Independen Exogenus terhadap Variabel Dependen Endogenus yang diformulasikan yang ditunjukkan pada persamaan (dibawah).

$\mathrm{BL}=\mathrm{f}(\mathrm{Pad}, \mathrm{Dau})$
$\mathrm{PE}=\mathrm{f}(\mathrm{BL})$

dimana,

$$
\begin{array}{ll}
\mathrm{BL} & =\text { Belanja Langsung } \\
\mathrm{PAD} & =\text { Pendapatan asli daerah } \\
\mathrm{DAU} & =\text { Dana Alokasi umum } \\
\mathrm{PE} & =\text { Pertumbuhan Ekonomi }
\end{array}
$$

Dari model fungsional persamaan (3.1) dan (3.1.1) dapat ditulis secara model ekonometrika sebagai berikut :

$$
\begin{aligned}
& \mathrm{BL}_{\mathrm{t}}=\beta_{0}+\beta_{1} \mathrm{PAD}_{\mathrm{t}}+\beta_{2} \mathrm{DAU}_{\mathrm{t}}+\mathrm{e}_{\mathrm{t}} \\
& \mathrm{PE}_{\mathrm{t}}=\beta_{0}+\beta_{1} \mathrm{BL}_{\mathrm{t}}+\mathrm{e}_{\mathrm{t}}
\end{aligned}
$$

dimana,

$$
\begin{aligned}
& \mathrm{BL}=\text { Belanja Langsung } \\
& \text { PAD = Pendapatan asli daerah } \\
& \text { DAU = Dana Alokasi umum } \\
& \mathrm{PE} \quad=\text { Pertumbuhan Ekonomi } \\
& \beta_{0} \quad=\text { konstanta (intersep) } \\
& \beta_{1}, \beta_{2}, \beta_{3}=\text { koefisien regresi dari masing-masing variabel bebas, } \\
& \mathrm{e} \quad=\text { error term } \\
& \mathrm{t}=\text { sampel } 10 \text { tahun (tahun 2006-2015) }
\end{aligned}
$$

Persamaan (3.2) dan (3.2.2) ditransformasikan kedalam bentuk log-natural seperti yang ditunjukkan persamaan (3.3) dan (3.3.1). Pentransformasian ke dalam bentuk log-natural bertujuan untuk menjadikan nilai variabel-variabel yang dianalisis menjadi seimbang dan juga sekaligus hasil output regresi menunjukkan koefisien slope merupakan tingkat perubahan variabel tidak bebas (dalam persen) bila terjadi perubahan variabel-variabel bebas (dalam persen) Nachrowi, (2006).

dimana,

$$
\begin{aligned}
& \mathrm{LBL}_{\mathrm{t}}=\beta_{0}+\beta_{1} \mathrm{PAD}_{\mathrm{t}}+\beta_{2} \mathrm{LDAU}_{\mathrm{t}}+\mathrm{e}_{\mathrm{t}} \\
& \mathrm{LPE}_{\mathrm{t}}=\beta_{0}+\beta_{1} \mathrm{BL}_{\mathrm{t}}+\mathrm{e}_{\mathrm{t}}
\end{aligned}
$$

$$
\begin{aligned}
& \text { LBL }=\text { Belanja Langsung } \\
& \text { LPAD }=\text { Pendapatan asli daerah } \\
& \text { LDAU }=\text { Dana Alokasi umum } \\
& \text { LPE }=\text { Pertumbuhan Ekonomi } \\
& \beta_{0} \quad=\text { konstanta (intersep) }
\end{aligned}
$$




$$
\begin{array}{ll}
\beta_{1}, \beta_{2}, \beta_{3} & =\text { koefisien regresi dari masing-masing variabel bebas, } \\
\mathrm{e} & =\text { error term } \\
\mathrm{t} & =\text { sampel } 10 \text { tahun (tahun 2006-2015) }
\end{array}
$$

Aplikasi model yang digunakan dalam penelitian ini adalh "Aplikasi Model Mediasi Melalui Variabel Perantara" Untuk model yang akan digunakan adalah dua veriabel independen yang berfungsi sebagai variabel exogenous dan dua variiabel dependen yang berfungsi sebagai variabel endogenous.sebagai variabel exogenous ialah Pendapatan pajak dan pendapatan retribusi sedangkan sebagai variabel endogenous pertama yang berfungsi sebagai variabel perantara ialah belanja langsung dan variabel endogenous yang kedua ialah pertumbuhan ekonomi. Hubungan antara variabel tersebut jika digambarkan kedalam model diagram jalur menjadi seperti di bawah ini :

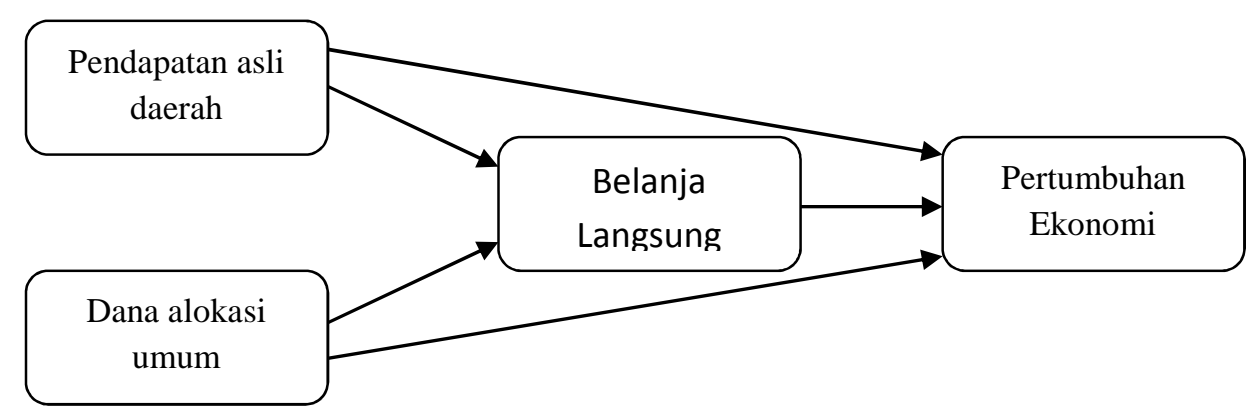

Gambar 1 Diagram Jalur pendapatan asli daerah dan dana alokasi umum terhadap belanja langsung dan dampaknya terhadap Pertumbuhan Ekonomi

\begin{tabular}{|c|c|c|c|c|c|c|}
\hline \multirow[t]{2}{*}{ Model } & \multirow[t]{2}{*}{$\mathrm{R}$} & \multirow[t]{2}{*}{ R Square } & \multirow{2}{*}{$\begin{array}{l}\text { Adjusted R } \\
\text { Square }\end{array}$} & \multirow{2}{*}{$\begin{array}{c}\text { Std. Error of the } \\
\text { Estimate }\end{array}$} & \multicolumn{2}{|c|}{ Change Statistics } \\
\hline & & & & & $\begin{array}{l}\text { R Square } \\
\text { Change }\end{array}$ & F Change \\
\hline 1 &, $942^{\mathrm{a}}$ & 887 & 859 & 09230 & ,887 & 31,385 \\
\hline
\end{tabular}

\section{HASIL PENELITIAN DAN PEMBAHASAN}

\section{Penghitungan Koefisien Determinasi}

a Predictors: (Constant), PAD, DAU

b Dependent Variable: Belanja Langsung

Sumber Data : pengolahan data 2017

Dalam melihat pengaruh Variabel Independen Exogenus PAD dan DAU secara gabungan terhadap variabel Dependen Endogenus belanja langsung dapat dilihat dari Tabel 1 Model Summary diatas, pada nilai $R$ square. Besarnya $R$ square $\left(R^{2}\right)$ pada tabel dibawah ini adalah 0,887 . Angka tersebut mempumpunyai makna Besarnya pengaruh Variabel indeependen exogenous PAD dan DAU terhadap variabel dependen endogenus alokasi belanja langsung secara gabungan. Dalam menghitung Koefisien Determinasi (KD) dapat diketahui dengan rumus

$$
\mathrm{KD}=\mathrm{R} 2 \times 100 \%
$$




$$
\begin{aligned}
\mathrm{KD} & =0,887 \times 100 \% \\
\mathrm{KD} & =88,7 \%
\end{aligned}
$$

Besarnya pengaruh Variabel Independen Exogenous PAD dan DAU terhadap Variabel Dependen Endogenus belanja langsung secara gabungan adalah $88,7 \%$.

Dan pengaruh di luar model dapat di hitung dengan rumus :

$$
\begin{aligned}
& \mathrm{e}=1-\mathrm{R}^{2} \\
& \mathrm{e}=1-0,887 \\
& \mathrm{e}=0,113 \times 100 \% \\
& \mathrm{e}=11,3 \%
\end{aligned}
$$

Yang berarti $11,3 \%$ besarnya faktor lain yang mempengaruhi diluar model yang di teliti. Artinya besarnya pengaruh variabel independen eksogenus PAD dan DAU terhadap variabel dependen endogenus belanja langsung adalah sebesar $88,7 \%$, sedangkan pengaruh sebesar 11,3\% disebabkan oleh variabel di luar model yang di teliti.

\section{Pengaruh variabel independen exogenous PAD dan DAU secara parsial terhadap

\begin{tabular}{|c|c|c|c|c|c|c|}
\hline \multirow{2}{*}{\multicolumn{2}{|c|}{ Model }} & \multicolumn{2}{|c|}{ Unstandardized Coefficients } & Standardized & \multirow[t]{2}{*}{$\mathrm{t}$} & \multirow[t]{2}{*}{ Sig } \\
\hline & & B & Std. Error & Beta & & \\
\hline \multirow{3}{*}{1} & (Constant) & $-1,757$ & 3,036 & &,- 579 &, 579 \\
\hline & PAD & 217 &, 190 &, 321 & 1,146 &, 285 \\
\hline & DAU &, 938 &, 410 & 641 & 2,287 &, 051 \\
\hline
\end{tabular} variabel dependen endogenus Belanja Langsung.}

Besarnya pengaruh variabel independen exogenous PAD dan DAU terhadap variabel dependen endogenus Belanja Langsung secara Parsial dapat dilihat dari nilai Beta atau Standardized Coefficients .dan untuk pengujian digunakan nilai t. Dapat dilihat pada Tabel 4.6 dibawah ini.

Tabel 2 Coefficients(a) t Hitung

Dependent Variable: belanja langsung

Sumber Data : pengolahan data 2017

\section{Pengaruh Variabel Independen Exogenous PAD terhadap Variabel Dependen Endogenus Belanja Langsung}

Untuk melihat apakah ada Pengaruh Linier Variabel Independen Exogenus Pajak terhadap Variabel Dependen Endogenus belanja langsung. Dapat dilihat pada tabel 4.6 Coefficients(a)

Dengan Analisis Hipotesis :

H0 : Tidak ada pengaruh linier antara Variabel Independen Exogenus PAD terhadap Variabel Dependen Endogenus Belanja Langsung.

H1 : Ada Pengaruh linier antara Variabel Independen Exogenus PAD terhadap Variabel Dependen Endogenus Belanja Langsung

Menentukan besarnya taraf Signifikan sebesar 0,05 dan Degree of Freedom DF $=n-(K+1)$ atau $\mathrm{DF}=10-(2+1)=7$. Dari ketentuan tersebut diperoleh t tabel sebesar 1,894 (untuk uji dua arah) Dalam perhitungan SPSS yang tertera pada tabel Coefficients di atas dimana t hitung adalah untuk menunjukan bahwa adanya Pengaruh linier antara Variabel Independen Exogenus Pendapatan PAD terhadap Variabel Dependen Endogenus Belanja Langsung ialah 1,146. 
Pengujian Hipotesis t kriterianya sebagai berikut :

Jika thitung $>\mathrm{t}$ tabel, maka $\mathrm{H} 0$ ditolak, dan $\mathrm{H} 1$ diterima

Jika thitung < t tabel, maka H0 diterima, dan $\mathrm{H} 1$ ditolak

Dimana dalam melihat pengaruh signifikan atau tidak Kriterianya adalah sebagai berikut :

Jika Signifikan $<0,05$ maka berpengaruh signifikan

Jika Signifikan >0,05 maka tidak ada pengaruh signifikan

Hasil dari perhitungan dengan SPSS menunjukan angka t hitung sebesar $1,146<\mathrm{t}$ tabel sebesar 1,894. Dengan demikian keputusanya ialah H0 diterima, dan H1 ditolak. Artinya tidak ada hubungan linier antara Variabel Independen Exogenus PAD terhadap Variabel Dependen Endogenus Belanja Langsung. Maka Variabel Independen Exogenus PAD tidak berpengaruh terhadap Variabel Dependen Endogenus Belanja Langsung. Besarnya Koefisien Beta pada tabel 4.6 di atas (dalam kolom Standardized Coefficient Beta) sebesar 0,321 atau jika dibuat persen menjadi sebesar 32,1\% menunjukan bahwa pengaruh sebesar ini tidak mampu menjelaskan perubahan yang terjadi pada Belanja Langsung, terlebih karena karena nilai signifikansi / probabilitas hasil yang tertera pada kolom Sig 0,28 > 0,05.

\section{Pengaruh antara variabel Independen Exogenus DAU terhadap Variabel Dependen Endogenus Belanja Langsung.}

Untuk melihat apakah ada Pengaruh Linier Variabel Independen Exogenus Pajak terhadap Variabel Dependen Endogenus belanja langsung. Dapat dilihat pada tabel 4.6 Coefficients(a) Dengan Analisis Hipotesis :

H0 : Tidak ada pengaruh linier antara Variabel Independen Exogenus DAU terhadap Variabel Dependen Endogenus Belanja Langsung.

H1 : Ada Pengaruh linier antara Variabel Independen Exogenus DAU terhadap Variabel Dependen Endogenus Belanja Langsung

Menentukan besarnya taraf Signifikan sebesar 0,05 dan Degree of Freedom DF $=\mathrm{n}-$ $(\mathrm{K}+1)$ atau $\mathrm{DF}=10-(2+1)=7$. Dari ketentuan tersebut diperoleh $\mathrm{t}$ tabel sebesar 1,894 (untuk uji dua arah) Dalam perhitungan SPSS yang tertera pada tabel Coefficients di atas dimana $t$ hitung adalah untuk menunjukan bahwa adanya Pengaruh linier antara Variabel Independen Exogenus Pendapatan PAD terhadap Variabel Dependen Endogenus Belanja Langsung ialah 2,287.

Pengujian Hipotesis t kriterianya sebagai berikut :

Jika $\mathrm{t}$ hitung $>\mathrm{t}$ tabel, maka $\mathrm{H} 0$ ditolak, dan $\mathrm{H} 1$ diterima

Jika thitung < t tabel, maka H0 diterima, dan $\mathrm{H} 1$ ditolak

Dimana dalam melihat pengaruh signifikan atau tidak Kriterianya adalah sebagai berikut :

Jika Signifikan $<0,05$ maka berpengaruh signifikan

Jika Signifikan >0,05 maka tidak ada pengaruh signifikan

Hasil dari perhitungan dengan SPSS menunjukan angka t hitung sebesar 2,287 > t tabel sebesar 1,894. Dengan demikian keputusanya ialah H0 ditolak, dan H1 diterima. Artinya ada hubungan linier antara Variabel Independen Exogenus PAD terhadap Variabel Dependen Endogenus Belanja Langsung. Maka Variabel Independen Exogenus DAU berpengaruh terhadap Variabel Dependen Endogenus Belanja Langsung. Besarnya Koefisien Beta pada tabel 4.6 di atas (dalam kolom Standardized Coefficient Beta) sebesar 0,641 atau jika dibuat persen menjadi sebesar $64,1 \%$ menunjukan bahwa pengaruh sebesar ini mampu menjelaskan perubahan yang terjadi pada Belanja Langsung pada tingkat koefisien sebesar 0,05.

\section{Melihat Kelayakan Model Regresi}

Untuk mengetahui model regresi yang telah dibuat sudah benar adalah dengan menggunakan pengujian dengan menggunakan pengujian dengan dua cara, yaitu Pertama 
menggunakan nilai $\mathrm{F}$ pada tabel keluaran ANOVA, dan Kedua dengan cara menggunakan nilai Probabilitas / nilai Sig pada tabel keluaran ANOVA.

Tabel 3 ANOVA(b)

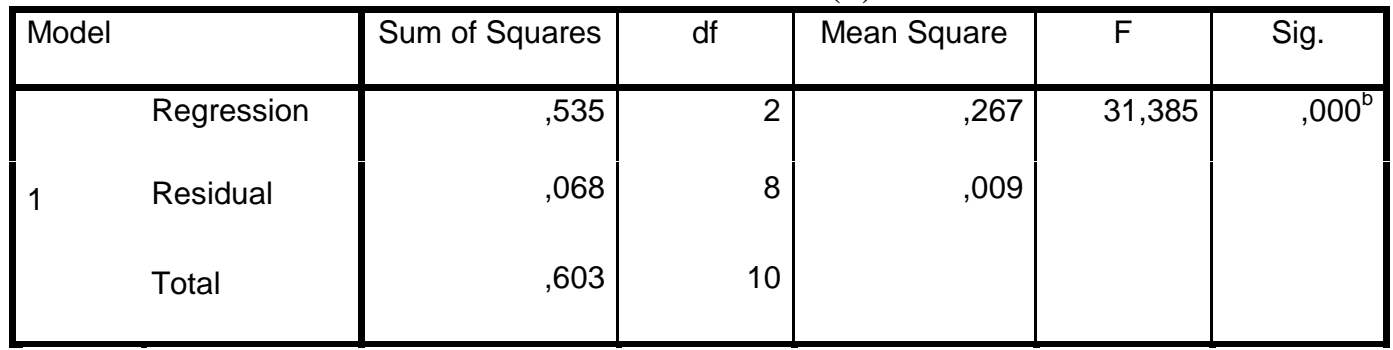

a. Dependent Variable: BL

b. Predictors: (Constant), DAU, PAD

Sumber Data : pengolahan data 2017

Uji Hipotesis Menggunakan Angka F. Hipotesis :

H0 : Tidak ada pengaruh linier antara Variabel Independen Exsogenus PAD dan DAU terhadap

Variabel Dependen Endogenus Belanja Langsung.

H1 : Ada pengaruh linier antara Variabel Independen Exogenus PAD dan DAU terhadap

Variabel Dependen Endogenus Belanja Langsung.

Menghitung nilai $\mathrm{F}$ tabel dengan Ketentuan besar nilai taraf Signifikansi sebesar 0,05 dan

Nilai Degree Of Freedom dengan ketentuan Numerator / Vektor 1 : Jumlah Variabel - 1 atau 3 - 1

$=2$, dan dumerator / Vektor $2:$ jumlah kasus-jumlah variabel atau $10-3=7$. Dengan ketentuan terdebut diperoleh angka $\mathrm{F}$ tabel sebesar 4,740.

Dengan kriteria pengambilan keputusan hasil pengujian hipotesis

Jika F hitung > F tabel, maka H0 ditolak, H1 diterima.

Jika F hitung < F tabel, maka H0 diterima dan H1 ditolak.

Hasil uji hipotesis adalah :

Hasil perhitungan dengan SPSS didapatkan angka $\mathrm{F}$ hitung sebesar 31,385 > F tabel sebesar 4,740.

Dengan demikian H0 ditolak, dan H1 diterima. Artinya ada hubungan linier antara Variabel Independen Eksogenus PAD dan DAU dengan Variabel Dependen Endogenus Belanja Langsung. Dengan nilai Sig 0,000 dengan demikian dapat diambil kesimpulan bahwa model regresi di atas sudah layak dan benar.

\section{Perhitungan Sub Struktur Ii}

\section{Pengaruh Variabel Independen Eksogenus PAD, DAU dan Belanja Langsung Secara} Gabungan Terhadap Variabel Dependen Endogenus Pertumbuhan Ekonomi.

Untuk melihat hubungan pengaruh variabel Independen Exogenus PAD, DAU dan Belanja Lansung terhadap Variabel Endogenus Kemiskinan secara gabungan dapat dilihat pada Tabel Model Summary, dalam angka R square di bawah ini. 
Tabel 4 Koefisien Determinasi(b)

\begin{tabular}{|c|c|c|c|c|c|c|}
\hline \multirow[t]{2}{*}{ Model } & \multirow[t]{2}{*}{$\mathrm{R}$} & \multirow[t]{2}{*}{ R Square } & \multirow{2}{*}{$\begin{array}{l}\text { Adjusted R } \\
\text { Square }\end{array}$} & \multirow{2}{*}{$\begin{array}{l}\text { Std. Error of the } \\
\text { Estimate }\end{array}$} & \multicolumn{2}{|c|}{ Change Statistics } \\
\hline & & & & & $\begin{array}{c}\text { R Square } \\
\text { Change }\end{array}$ & F Change \\
\hline 1 &, $976^{\mathrm{a}}$ & ,953 & ,933 &, 01842 & ,953 & 47,436 \\
\hline
\end{tabular}

a Predictors: (ConstantPAD, DAU, Belanja Langsung

b Dependent Variable: Pertumbuhan Ekonomi

Sumber Data : pengolahan data 2017

besarnya pengaruh Rsquare $\left(\mathrm{R}^{2}\right)$ pada tabel diatas adalah 0,953. Angka tersebut mempunyai makna besarnya pengaruh variabel independen exogenous PAD, DAU dan Belanja Langsung terhadap Pertumbuhan Ekonomi secara gabungan. dalam menghitung Koefisien Determinasi (KD) dapat di hitung dengan Rumus sebagai berikut.

$$
\begin{aligned}
& \mathrm{KD}=\mathrm{R} 2 \times 100 \% \\
& \mathrm{KD}=0,953 \times 100 \% \\
& \mathrm{KD}=95,3 \%
\end{aligned}
$$

Angka 95,3\% mempunyai makna besarnya pengaruh Variabel Independen Exogenus PAD, DAU dan Belanja Langsung terhadap Pertumbuhan Ekonomi secara gabungan. sedangkan sisanya dapat dihitung dengan menggunakan rumus sebagai berikut :

$$
\begin{aligned}
& \mathbf{e}=1-\mathrm{R} 2 \\
& \mathbf{e}=1-0,953 \\
& \mathbf{e}=0,047 \\
& \mathbf{e}=0,047 \times 100 \% \\
& \mathbf{e}=4,7 \%
\end{aligned}
$$

Variabelitas Pertumbuhan Ekonomi yang dapat diterangkan dengan menggunakan Variabel Independen Exogenus PAD, DAU dan Belanja Langsung adalah sebesar 95,3 \% , sedangkan besarnya pengaruh dari Variabel diluar model adalah sebesar 4,7 \%.

\section{Pengaruh Variabel Independen Exogenus PAD, DAU dan Belanja Langsung secara Parsial terhadap Variabel Dependen Endogenus kemiskinan.}

Besarnya pengaruh Variabel Independen Exogenus PAD, DAU dan Belanja Langsung terhadap Pertumbuhan Ekonomi secara Parsial. 
Tabel 5 Coefficients(a)

\begin{tabular}{|c|c|c|c|c|c|}
\hline \multirow[t]{2}{*}{ Model } & \multicolumn{2}{|c|}{ Unstandardized Coefficients } & \multirow{2}{*}{$\begin{array}{c}\text { Standardized } \\
\text { Coefficients }\end{array}$} & \multirow[t]{2}{*}{$\mathrm{t}$} & \multirow[t]{2}{*}{ Sig. } \\
\hline & B & Std. Error & & & \\
\hline (Constant) & 3,341 & ,619 & & 5,401 &, 001 \\
\hline $\mathrm{BL}$ & 059 & ,071 & 204 & ,839 & , 429 \\
\hline DAU & 335 & 105 & -790 & 3,181 & , 015 \\
\hline PAD &,- 352 & 041 & $-1,791$ & $-8,604$ & , 000 \\
\hline
\end{tabular}

a Dependent Variable: Pertumbuhan Ekonomi

Sumber Data : pengolahan data 2017

\section{Pengaruh antara variabel Independen Exogenus PAD dengan Variabel Dependen Endogenus Pertumbuhan Ekonomi.}

Dengan hipotesis :

H0 : Tidak ada pengaruh linier antara variabel Independen Eksogenus PAD terhadap Variabel Dependen Endogenus Pertumbuhan Ekonomi

H1 : Adanya pengaruh linier antara Variabel Independen Exogenus PAD terhadap Variabel Dependen Endogenus Pertumbuhan Ekonomi

Dari hasil perhitungan dengan menggunakan SPSS yang tertera pada kolom $\mathrm{t}$ pada tabel Coefficients diatas untuk menunjukan adanya hubungan linier antara Variabel Independen Exogenus PAD dengan Variabel Dependen Endogenus Pertumbuhan Ekonomi ialah sebesar -8,604. Menentukan besarnya angka $t$ tabel / nilai kritis dari tabel $t$ dengan ketentuan sebagai berikut :

Menentukan besarnya taraf signifikansi sebesar 0,05 dan Degree of Freedom DF dengan ketentuan : $\mathrm{DF}=\mathrm{n}-(\mathrm{K}+1)$ atau $\mathrm{DF}=10-(4+1)$ dari ketentuan tersebut diperoleh angka t tabel untuk uji dua sisi adalah sebesar 2,015. Dalam pengujian hipotesis $t$ kriterianya sebagai berikut :

Jika t hitung > t tabel, maka H0 di tolak. Dan H1 diterima

Jika t hitung < t tabel, maka H0 diterima. Dan H1 ditolak

Untuk menunjukan pengaruh signifikan atau tidak kriterianya sebagai berikut :

Jika Sig $<0,05$, maka berpengaruh Signifikan

Hasil Pengujian :

Jika Sig > 0,05, maka tidak berpengaruh Signifikan

Hasil dari perhitungan dengan menggunakan SPSS menunjukan angka t hitung sebesar -8,604 < 2,015, dengan demikian keputusanya adalah H0 diterima, dan H1 ditolak. Artinya tidak ada hubungan linier antara Variabel Independen PAD terhadap Variabel Dependen Endogenus Pertumbuhan Ekonomi.

\section{Pengaruh antara Variabel Independen Exsogenus DAU terhadap Variabel Independen Endogenus Pertumbuhan Ekonomi.}

Dengan hipotesis :

H0 : Tidak ada pengaruh linier antara variabel Independen Eksogenus DAU terhadap Variabel Dependen Endogenus Pertumbuhan Ekonomi 
H1 : Adanya pengaruh linier antara Variabel Independen Exogenus DAU terhadap Variabel Dependen Endogenus Pertumbuhan Ekonomi

Dari hasil perhitungan dengan menggunakan SPSS yang tertera pada kolom $\mathrm{t}$ pada tabel Coefficients diatas untuk menunjukan adanya hubungan linier antara Variabel Independen Exogenus DAU dengan Variabel Dependen Endogenus Pertumbuhan Ekonomi ialah sebesar 3,181.

Menentukan besarnya angka t tabel / nilai kritis dari tabel $t$ dengan ketentuan sebagai berikut :

Menentukan besarnya taraf signifikansi sebesar 0,05 dan Degree of Freedom DF dengan ketentuan : $\mathrm{DF}=\mathrm{n}-(\mathrm{K}+1)$ atau $\mathrm{DF}=10-(4+1)$ dari ketentuan tersebut diperoleh angka t tabel untuk uji dua sisi adalah sebesar 2,015.

Dalam pengujian hipotesis $\mathrm{t}$ kriterianya sebagai berikut :

Jika t hitung > t tabel, maka H0 di tolak. Dan H1 diterima

Jika thitung < t tabel, maka H0 diterima. Dan H1 ditolak

Untuk menunjukan pengaruh signifikan atau tidak kriterianya sebagai berikut :

Jika Sig $<0,05$, maka berpengaruh Signifikan

Jika Sig > 0,05, maka tidak berpengaruh Signifikan

Hasil Pengujian :

Hasil dari perhitungan dengan menggunakan SPSS menunjukan angka t hitung sebesar 3,181 > 2,015, dengan demikian keputusanya adalah H0 ditolak, dan H1 diterima. Artinya ada hubungan linier antara Variabel Independen DAU terhadap Variabel Dependen Endogenus Pertumbuhan Ekonomi. Besarnya Koefisien Beta pada tabel 4.11 di atas (dalam kolom Standardized Coefficient Beta) sebesar 0,790 atau jika dibuat persen menjadi sebesar $79 \%$ menunjukan bahwa pengaruh sebesar ini mampu menjelaskan perubahan yang terjadi pada Belanja Langsung.

\section{Pengaruh antara Variabel Independen Exsogenus Belanja Langsung terhadap Variabel Independen Endogenus Pertumbuhan Ekonomi.}

Dengan hipotesis :

H0 : Tidak ada pengaruh linier antara variabel Independen Eksogenus Belanja Langsung terhadap Variabel Dependen Endogenus Pertumbuhan Ekonomi

H1 : Adanya pengaruh linier antara Variabel Independen Exogenus Belanja Langsung terhadap Variabel Dependen Endogenus Pertumbuhan Ekonomi

Dari hasil perhitungan dengan menggunakan SPSS yang tertera pada kolom t pada tabel Coefficients diatas untuk menunjukan adanya hubungan linier antara Variabel Independen Exogenus Belanja Langsung dengan Variabel Dependen Endogenus Pertumbuhan Ekonomi ialah sebesar 0,839 .

Menentukan besarnya angka t tabel / nilai kritis dari tabel t dengan ketentuan sebagai berikut :

Menentukan besarnya taraf signifikansi sebesar 0,05 dan Degree of Freedom DF dengan ketentuan : $\mathrm{DF}=\mathrm{n}-(\mathrm{K}+1)$ atau $\mathrm{DF}=10-(4+1)$ dari ketentuan tersebut diperoleh angka $t$ tabel untuk uji dua sisi adalah sebesar 2,015.

Dalam pengujian hipotesis $t$ kriterianya sebagai berikut :

Jika t hitung > t tabel, maka H0 di tolak. Dan H1 diterima

Jika thitung < t tabel, maka H0 diterima. Dan H1 ditolak

Untuk menunjukan pengaruh signifikan atau tidak kriterianya sebagai berikut :

Jika Sig <0,05, maka berpengaruh Signifikan

Jika Sig > 0,05, maka tidak berpengaruh Signifikan

Hasil Pengujian :

Hasil dari perhitungan dengan menggunakan SPSS menunjukan angka t hitung sebesar $0,839<$ 2,015, dengan demikian keputusanya adalah H0 diterima, dan H1 ditolak. Artinya tidak ada hubungan linier antara Variabel Independen DAU terhadap Variabel Dependen Endogenus Pertumbuhan Ekonomi. 


\section{Melihat Kelayakan Model Regresi Struktur II}

Untuk mengetahuimodel Regresi yang dibuat telah benar adalah dengan menggunakan Pengujian dua cara yaitu pertama menggunakan nilai $\mathrm{F}$ pada tabel keluaran ANOVA, dan kedua dengan cara menggunakan nilai Probabilitas nilai Sig pada tabel keluaran ANOVA.

Tabel 6 Anova

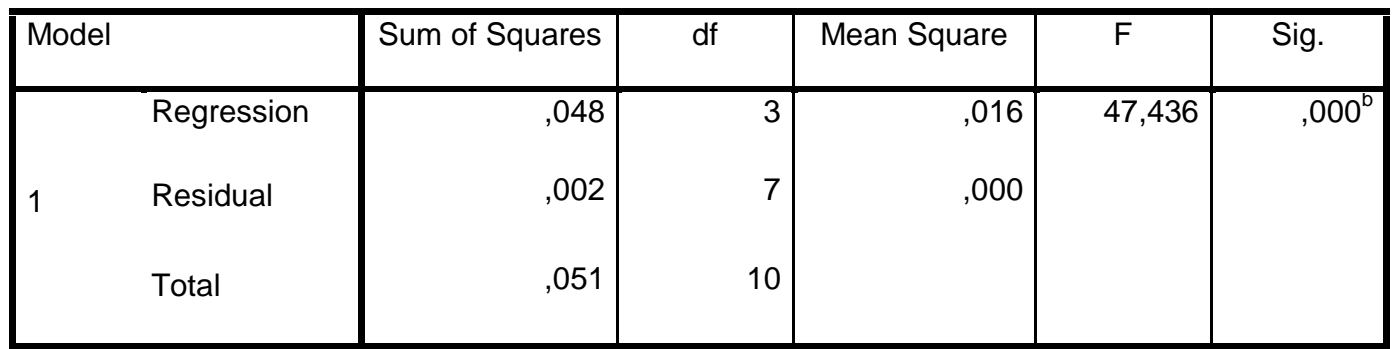

a. Dependent Variable: KEMISKINAN

b. Predictors: (Constant), PAD, BL, DAU

Uji Hipotesis Menggunakan Angka F. Hipotesis :

H0 : Tidak ada pengaruh linier antara variabel Independen Exogenous PAD, DAU dan Belanja

Langsung terhadap variabel Dependen Endogenus Pertumbuhan Ekonomi

H1 : ada hubungan linier antara variabel Independen Eksogenus PAD, DAU dan belanja langsung terhadap variabel Dependen Endogenus Pertumbuhan Ekonomi

Nilai F hitung dari keluaran SPSS ialah 47,436

Menghitung nilai $\mathrm{F}$ tabel dengan ketentuan nilai besar nilai taraf signifikasi sebesar 0,05 dan nilai DF / Vektor 1 : jumlah variabel -1 atau 4-1 = 3 dan dumerator Vektor : jumlah kasus - jumlah variabel atau $10-4=6$ dengan ketentuan tersebut diperoleh angka $F$ tabel sebesar 4,76.

Dengan kriteria pengambilan keputusan hasil pengujian hipotesis

Jika F hitung > F tabel, maka H0 ditolak, H1 dan diterima.

Jika $\mathrm{F}$ hitung $<\mathrm{F}$ tabel, maka $\mathrm{H} 0$ diterima dan $\mathrm{H} 1$ ditolak

Hasil perhitungan dengan SPSS didapat angka F hitung sebesar 47,436 > F tabel sebesar 4,76. Dengan demikian H0 ditolak, dan H1 diterima dengan demikian Ada pengaruh linier antara variabel Independen Exogenus PAD, DAU dan Belanja Langsung terhaddap variabel Dependen Endogenus Pertumbuhan Ekonomi. Kesimpulan yang dapat diambil adalah adalah model regresi diatas sudah layak dan benar.

\section{Menghitung Pengaruh Langsung DE (Direct Effect)}

Pengaruh Variabel PAD terhadap Belanja Langsung

$\mathrm{X} 1 \mathrm{ke} \mathrm{Y} 1=1,146$

Pengaruh Variabel DAUterhadap Belanja Langsung

$\mathrm{X} 2$ ke $\mathrm{Y} 1=2,287$

Pengaruh Variabel PAD terhadap Pertumbuhan Ekonomi

$\mathrm{X} 1 \mathrm{ke} \mathrm{Y} 2=-8,604$

Pengaruh Variabel DAU terhadap Pertumbuhan Ekonomi

$\mathrm{X} 2$ ke $\mathrm{Y} 2=3,181$

Pengaruh Variabel Belanja Langsung terhadap Pertumbuhan Ekonomi

Y1 ke Y2 = 0,839

\section{Pengaruh Tidak Langsung IE (Indirect Effect)}

Pengaruh variabel PAD terhadap Pertumbuhan Ekonomi Melalui Belanja Langsung 


$$
\begin{aligned}
& \text { PY1X1 x PY2Y1 }=(1,146 \times 0,839)=1,224 \\
& \text { Pengaruh variabel Retribusi terhadap Pertumbuhan Ekonomi melalui Belanja Langsung } \\
& \text { PY1X2 x PY2Y1 }=(2,287 \text { x 0,839) }=1,918
\end{aligned}
$$

\section{Pengaruh Total (Total Effect)}

Pengaruh Variabel PAD dan Belanja Langsung terhadap Pertumbuhan Ekonomi PY1X1 + PY2Y1 $=1,146+0,839=1,985$

Pengaruh Variabel DAU dan Belanja langsung tehadap Pertumbuhan Ekonomi $\mathrm{PY} 1 \mathrm{X} 2+\mathrm{PY} 2 \mathrm{Y} 1=2,287+0,839=3,126$

\section{PEMBAHASAN}

Berdasarkan hasil penghitungan yang dilakukan mendapatkan hasil bahwa secara langsung PAD dan DAU memberi kontribusi positif dan signifikan terhadap alokasi belanja langsung di Kota Bitung secara bersama-sama, namun berdasarkan penghitungan apabila secara sendiri-sendiri PAD tidak memberi pengaruh atau tidak mampu menjelaskan perubahan yang terjadi pada alokasi belanja langsung, sedangkan DAU memberi pengaruh yang sangat positif dan signifikan terhadap alokasi belanja langsung kota Bitung, hal ini dapat diartikan bahwa DAU dapat menjelaskan dengan baik perubahan yang terjadi pada alokasi Belanja Langsung di Kota Bitung. Hal ini menjadi salah satu gambaran bahwa masih rendahnya pendapapatan asli daerah di Kota Bitung dan masih sangat bergantung pada alokasi anggaran dari pemerintah pusat dalam bentuk dana alokasi umum. Dengan demikian maka pemerintah kota Bitung sebagai pengelola anggaran belum bisa memaksimalkan pembangunan yang ada di Kota bitung dikarenakan rencana pembangunan maupun penggunaan anggaran masih amat bergantung pada alokasi DAU dari pemerintah pusat. Hal yang hampir sama juga terjadi pada bagaimana alokasi anggaran belanja langsung yang dilakukan pemerintah bitung dalam mempengaruhi kemiskinan, namun berdasarkan hasil penghitungan alokasi belanja langsung yang dilakukan pemerintah kota Bitung memberi pengaruh yang sangat besar dan signifikan terhadap upaya untuk mereduksi kemiskinan yang ada di kota Bitung. Dimana pemerintah kota Bitung dalam upaya mengurangi tingkat kemiskinan yang ada di daerah masih amat bergantung pada anggaran belanja langsung atau belanja pembangunan yang langsung berhubungan dengan publik dalam upayanya mengurangi kemiskinan, kemiskinan yang ada di Kota Bitung dapat lebih tereduksi kian jauh lagi apabila alokasi belanja pembangunan yang dimiliki oleh kota Bitung lebih ditingkatkan lagi, namun dikarenakan pemerintah Kota Bitung dalam mengatur alokasi belanja yang dimiliki masih amat bergantung pada kucuran dana dari pemerintah pusat menyebabkan masih kurangnya peningkatan dalam hal alokasi anggaran yang dimiliki. Berdasarkan hal tersebut dapat diambil tiga kesimpulan :

\section{Tingkat pengangguran dan kualitas tenaga kerja}

Sebagai dampak melambatnya pertumbuhan ekonomi kota Bitung berimplikasi terhadap lapangan pekerjaan sehingga tingkat pengangguranpun mengalami peningkatan. Dimana Tingkat pengangguran terbuka Kota Bitung Tahun 2013 sebesar 10,48 persen meningkat dibandingkan dengan tahun 2012 sebesar 9,75 persen. Sedangkan Tingkat partisipasi angkatan kerja Kota Bitung tahun 2013 berdasarkan Data BPS Kota Bitung yakni mencapai 61,58 persen. Pengangguran Terbuka diperkirakan masih akan meningkat di tahun 2015. Rendahnya kualitas tenaga kerja juga merupakan tantangan dimana dilihat dari indikator kualitas pendidikan yang dimiliki tenaga kerja mayoritas berpendidikan SLTA. Demikian pula halnya dilihat dari sisi penguasaan ketrampilan/keahlian sebagai modal untuk melakukan kreatifitas dan inovasi-inovasi, dimana tenaga kerja kita memiliki keahlian dalam bidang otomotif, teknik pendingin, instalasi penerangan, menjahit, komputer/ IT, las, mesin produksi, bahasa inggris/Asing, elektronika, TU perkantoran 
dan mobil diesel. Masalah pemerataan pendidikan khususnya pendidikan tinggi disadari masih menjadi isu sentris karena layanan memperoleh akses pendidikan tinggi bagi anak-anak yang berasal dari keluarga tidak mampu cenderung terbatas karena pendidikan tinggi membutuhkan biaya yang relatif besar. Hal ini tentunya menjadi perhatian pemerintah daerah dalam rencana pembangunan di tahun 2016, untuk lebih meningkatkan produktivitas dan kualitas produksi yang akan menjadi kontribusi peningkatan pertumbuhan ekonomi, sehingga dapat mengurangi persentase pengangguran. Selain itu untuk mencapai kondisi tersebut, maka iklim investasi di Kota Bitung akan terus diupayakan semakin membaik dan berkembang lewat peningkatan peran swasta. Kebijakan lain yang akan diambil pemerintah daerah di tahun 2016 yaitu akan melakukan peningkatan kualitas tenaga kerja profesional yang berkualitas dan tenaga trampil lewat berbagai program/kegiatan yang dilaksanakan oleh berbagai SKPD terkait sehingga diharapkan upaya menurunkan tingkat pengangguran dan peningkatan kualitas tenaga kerja dapat tercapai.

\section{Jumlah penduduk miskin yang masih cukup tinggi}

Perkembangan kondisi ekonomi makro di Kota Bitung pada dasarnya menunjukan perkembangan yang cukup baik dari tahun ke tahun. Kondisi ini tentunya cukup menggembirakan. Tahun 2012 hingga 2013, pertumbuhan ekonomi Kota Bitung dapat mencapai angka rata-rata diatas 7 persen. Pendapatan perkapita masyarakat meningkat dari Rp. 18.466 .400 pada Tahun 2012 menjadi Rp. 21.092.925 pada Tahun 2013. Namun demikian dibalik keberhasilan tersebut, sampai saat ini berdasarkan data dari Badan Pusat Statistik Kota Bitung bahwa Kota Bitung masih memiliki penduduk miskin sebanyak 12.900 jiwa (6,45 persen) Tahun 2013. Angka ini mengalami penurunan jika dibandingkan dengan tahun 2012, yang mencerminkan bahwa upaya pengentasan kemiskinan terpadu dan berkelanjutan yang dilakukan oleh Pemerintah Kota Bitung telah membuahkan hasil yang positif. namun hal ini perlu mendapat perhatian pemerintah daerah untuk terus menerus diupayakan penanggulangannya. Dalam rangka upaya untuk semakin lebih memaksimalkan usaha-usaha penanggulangan kemiskinan di Kota Bitung antara lain melalui berbagai program kegiatan sebagai berikut :

1. Program Keluarga Harapan (PKH)

2. Program Nasional Pemberdayaan Masyarakat (PNPM) Mandiri Perkotaan

3. Program Pelayanan Jaminan Kesehatan Nasional (BPPJS)

4. Program Pemberdayaan Koperasi dan UKM

5. Program Bantuan Perumahan

6. Program Pengembangan Usaha Mina Pedesaan Perikanan Tangkap dan Perikanan Budidaya.

Dengan berbagai kebijakan program / kegiatan yang terus dilaksanakan pemerintah saat ini diharapkan dapat semakin menurunkan tingkat kemiskinan masyarakat Kota Bitung.

\section{Peningkatan pertumbuhan ekonomi}

Pada Tahun 2013 pertumbuhan ekonomi mengalami perlambatan pada besaran 7,92 persen dibandingkan dengan tahun 2012 sebelumnya sebesar 7,98 persen. Dengan melihat kondisi tersebut pemerintah akan terus berupaya untuk meningkatkan kinerja perekonomian agar pertumbuhan ekonomi Kota Bitung pada tahun 2015 bisa mengalami peningkatan. Dorongan utama akan diberikan pemerintah bagi peningkatan produksi sektor angkutan dan komunikasi, sektor industri pengolahan, dan sektor pertanian khususnya sub sektor perikanan sebagai sektor unggulan Kota Bitung. Peran pihak swasta dan masyarakat tentunya sangat diharapkan karena pihak swasta sebagai pemilik kapital adalah pelaku utama ekonomi. Pemerintah akan terus mendorong peran perbankan dalam penyaluran modal baik investasi maupun modal kerja bagi swasta dan masyarakat. Dengan berkembangnya investasi swasta, lapangan kerja akan meningkat, sehingga dengan demikian pendapatan masyarakat ikut meningkat, yang mendorong kepada terciptanya daya beli serta 
meningkatnya permintaan terhadap barang dan jasa yang pada akhirnya dapat meningkatkan produksi dan produktifitas berbagai sektor ekonomi daerah. Pemerintah akan terus melakukan pembenahan berbagai kendala yang masih menghambat peningkatan produksi dan investasi sehingga seiring dengan peran swasta yang terus meningkat, maka pertumbuhan ekonomi kota Bitung diharapkan terus mengalami peningkatan.

\section{DAFTAR PUSTAKA}

Ahmad Yani. 2002. Hubungan Keuangan Antara Pemerintah Pusat dan Daerah di Indonesia. Jakarta: Raja Grafindo Persada.

Ali Sulieman AL-Shatti, 2014, The impact of public expenditure on economic growth in Jordan Ala, Andre Bayo, 1996, Kemiskinan dan strategi memerangi kemiskinan. Yogyakarta : Penerbit Libety.

Bastian, Indra, Gatot Soepriyanto, 2002. Sistem Akuntansi Sektor Publik Konsep Untuk Pemerintah Daerah, Edisi Pertama, Salemba Empat, Jakarta.

Burhanuddin, 2010, Aspek Hukum Lembaga Keuangan Syariah. Yogyakarta. Graha Ilmu

Badan Pusta Statistik Propinsi Sulawesi Utara

Cynaida Miriam Kwendo, 2015, The Effect of Public expenditure on economics growth in the east africcan community

David, Garson, 2003. Path Analysis. North Carolina State University.

Fatukasi A, Adebayo, Adebidi T, Adebusuyi, Mamidu A, Ishola, 2014, An Econometric Analysis of impact of Public Expenditure on industrial growth in Nigeria

Gabriel Chipaumire, HlanganipaiNrirande, Mangena Method, Yewukai Ruswa, 2014, The impact of government spending on economics growth : Case South Africa

Halim, Abdul dan Mujib, Ibnu, 2009, Problem desentralisasi dan perimbangan keuangan pemerintahan pusat-daerah peluang dan tantangan dalam pengelolaan sumber daya daerah, Tesis Sekolah Pascasarjanan UGM, Yogyakarta.

Halim, Abdul, 2004, Akuntansi Keuangan Daerah, Penerbit Salemba Empat, Jakarta

Jonathan Sarwono, 2006, Metode Penelitian Kuantitatif \& Kualitatif, (Yogyakarta; Graha Ilmu, John Njenga Muthui, George kosimbei, james Maingi, 2013, The impact of public expenditure components on economics growth in Kenya 1964-2011

Kuncoro, Mudrajat, 2007, Metode Kuantitatif, Teori dan Aplikasi untuk Bisnis dan Ekonomi, UPP STIM YKPN, Yogyakarta.

Kuncoro Mudrajat, 2000, Ekonomi Pembangunan Teory Masalah dan kebijakan, Yogyakarta : Penerbit UPP AMP YKPN

Li Yang Zi, 2016, An Empirical research on the Structur of Public Expenditure and Economic Growth - Evidence from China

Mardiasmo. 2002. Akuntansi Sektor Publik. Penerbit Andi. Yogyakarta.

Mohammed A Al Mahish, 2016, The impact of financing on economic growth in Saudi Arabia

Nahu Daud, 2016, The influence of economic growth on degree of autonomy of the regions and the absorption of labor and social welfare : regencies and cities of Maluku province

Niloy Bose, 2007, Public expenditure and economic growth : A Disaggegated Analysis for Developing countries

Nworji, Ifeanyi Desmond, 2012, Effect of public expenditure on economic growth in Nigeria

Peraturan Pemerintah No. 58 Tahun 2005 Tentang Pengelolaan Keuangan Daerah Panduan Keluarga Sejahtera, 1996.

Sofia Anwar, Ghulam Shabir, Zakir Husain, 2011, Relationship between financial sector development and sustainable economic development : time series ananlysis from Pakistan 
Sadono Sukirno, 2006, Ekonomi Pembangunan Proses masalah dan Dasar Kebijakan, cetakan ketiga, Penerbit Kencana, Jakarta.

Saragih, Juli Panglima. 2003. Desentralisasi Fiskal dan Keuangan Daerah dalam Otonomi. Cetakan Pertama. Penerbit Ghalia Indonesia: Jakarta

S.M Kapunda, J.S Topen, 2013, Public Expenditure Composition an economic growth in Tanzania

Seyed Hossein Ghaffarian Kolahi, Zaleha Bt Mohd Noor, 2016, The Effect of value add tax on economic growth and it sources in developing countries

Tajudeen Egbetunde, Ismail, O Fasanya, 2013, Public Expenditure and economic growth in Nigeria : Evidence from Auto-regresive Distributed lag specification

Undang-Undang No.32 Tahun 2004 Tentang Pemerintahan Daerah (Lembaran Negara Republik Indonesia Tahun 2004 Nomor 125)

Undang-Undang No.33 tahun 2004 Tentang Perimbangan Keuangan Antara Pemerintah Pusat Dan Pemerintah Daerah. ( Lembaran Negara Republik Indonesia Tahun 2004 Nomor 126)

V.Selvan, Desti Kannaiah, 2015, FDI in Retailing : Lead to economics growth and better value to end consumers 